\title{
Effect of Establishment Techniques and Sowing Time on Yield and Yield Attributes of Proso Millet (Panicum miliaceum L.)
}

\author{
H.D. Gavit, V.A. Rajemahadik, G.K. Bahure*, M.S. Jadhav, \\ T.N. Thorat and M.C. Kasture \\ College of Agriculture, Dr. Balasaheb Sawant Konkan Krishi Vidhyapeeth, Dapoli, India \\ *Corresponding author
}

\section{A B S T R A C T}

The experiment was conducted at department of Agronomy, College of Agriculture, Dapoli, Dist. Ratnagiri during kharif, season 2015.The present investigation was carried out in strip plot design with three replications. The treatments comprised of three sowing time viz; sowing of proso millet in $23^{\text {rd }}$ metrological week (MW), $25^{\text {th }}$ MWand $27^{\text {th }}$ MWand treatments constituted four establishment techniques viz., drilling at $20 \mathrm{~cm}$, broadcasting, transplanting at $20 \mathrm{~cm} \mathrm{x} 15 \mathrm{~cm}$ and awatni. Thus, there were in all twelve (12) treatment

Keywords

Proso millet, Sowing time, Establishment method, yield and yield attributes.

Article Info

Accepted: 17 April 2017 Available Online: 10 May 2017 combinations. The gross plot size was $4.2 \mathrm{~m}$ x $3.3 \mathrm{~m}$ and net plot size was $3.8 \mathrm{~m} \times 3.0 \mathrm{~m}$, respectively. The soil of the experimental plot was fairly levelled and uniform in topography with well drained conditions. The soil of the experiment plot was sandy clay loam in texture, low in available nitrogen $\left(247.43 \mathrm{~kg} \mathrm{ha}^{-1}\right)$ and phosphorus (10.92 $\left.\mathrm{kg} \mathrm{ha}-1\right)$ and moderately high in available potassium (229.62 $\left.\mathrm{kg} \mathrm{ha}^{-1}\right)$, very high in organic carbon (11.57) and moderately acidic in reaction $\left(\mathrm{p}^{\mathrm{H}}\right.$ 5.51). The seeds of proso millet were sown at different sowing times viz., $10^{\text {th }}$ Jun ( $23^{\text {rd }}$ MW), $24^{\text {th }}$ Jun $\left(25^{\text {th }} \mathrm{MW}\right)$ and $8^{\text {th }}$ July $\left(27^{\text {th }} \mathrm{MW}\right)$ 2015 with different establishment techniques viz; Drilling, Broadcasting, Transplanting and awatni. Sowing of proso millet in $25^{\text {th }} \mathrm{MW}$ produced maximum and significantly higher grain yield $\left(9.26 \mathrm{q} \mathrm{ha}^{-1}\right)$ and straw yield (33.00 $\mathrm{q} \mathrm{ha}^{-1}$ ) over rest of sowing times. The magnitude of increase in grain yield recorded by sowing of proso millet in $25^{\text {th }} \mathrm{MW}$ over the crop sown in $23^{\text {rd }} \mathrm{MW}$ and $27^{\text {th }} \mathrm{MW}$ was $2.09,3.69$ per cent, respectively. The increase in straw yield recorded due to the crop sown in $25^{\text {th }} \mathrm{MW}$ over $23^{\text {rd }}$ and $27^{\text {th }} \mathrm{MW}$ was $8.65,12.74$ per cent, respectively, Transplanting of proso millet produced maximum and significantly higher grain yield (10.15 q ha $\left.{ }^{-1}\right)$ and straw yield (36.21 q ha $\left.{ }^{-1}\right)$ over rest of the establishment techniques followed by awatni. The magnitude of increase in grain yield recorded by transplanting over awatni, drilling and broadcasting was 5.50, 18.02, and 27.19 per cent, respectively. The per cent increase in straw yield recorded due to transplanting over awatni, drilling and broadcasting was to the tune of $10.80,29.92$ and 35.31 , respectively.

\section{Introduction}

Proso millet (Panicum miliaceum L.) is locally known as Vari or common millet, is one of the ancient cultivation, probably domesticated in Central and Eastern Asia, it was introduced into North America after the

arrival of Columbus. Most Proso millet traded internationally is imported by the pet-food industry in industrialized countries which is used as bird feed. In tropical Africa, it is cultivated in Ethiopia, Eastern Kenya, 
Malawi, Botswana, Zimbabwe and Madagascar. In India small millet is cultivated over an area of 0.0719 million ha with total production of 0.435 million tonnes during 2012-13 (Anonymous, 2013). In Maharashtra, the largest area is found in Konkan region comprising Raigad, Thane, Sindhudurg and Ratnagiri districts.

In India, Proso millet is grown mostly in Southern India although it is cultivated in scattered localities in central and hilly tract of North India. Statistics regarding the area and production with special reference to the Proso millet has not been reported so far. However combined values for minor millets have appeared in some report in which Proso millet is considered. It is commonly grown in Madhya Pradesh, Eastern Uttar Pradesh, Bihar, Tamil Nadu, Maharashtra, Andra Pradesh and Karnataka. It is important minor millet being a short duration crop (110-115 days) with relatively low water requirement, it escapes drought period. The seeds are rich source of protein (12-13\%) and have long storability under ambient conditions and hence, suitable as famine reserve. It is rich in lysine as high as $4.6 \%$ of the total proteins. In addition to protein, it also contains about 1.1 $\%$ crude fat, $68.9 \%$ carbohydrates, 2-3\% minerals and $2.2 \%$ crude fiber.

Proso millet contains large proportion of carbohydrates $(72.9 \%)$ and thus provides bulk of energy in diets (378 kcal). It also contains fat $(4.2 \%)$, protein $(11 \%)$ and dietary fiber $(8.5 \%)$. Apart from the major nutrients, each 100 grams of Proso millet consist of calcium $8 \mathrm{mg}$, magnesium $114 \mathrm{mg}$, phosphorus $285 \mathrm{mg}$, iron $3.0 \mathrm{mg}$ etc. The essential amino-acid composition per 100 grams of edible portion is tryptophan $119 \mathrm{mg}$, methionine $221 \mathrm{mg}$, leucine $1400 \mathrm{mg}$ and isoleucine $465 \mathrm{mg}$. The principal fatty acids are (per $100 \mathrm{~g}$ edible portion) linoleic acid $2015 \mathrm{mg}$, oleic acid $739 \mathrm{mg}$, palmitic acid
$528 \mathrm{mg}$ and linolenic acid $118 \mathrm{mg}$ (Anonymous, 2010).

Various medicinal uses of Proso millet have been recorded in Asia. The seeds of Proso millet are used as a demulcent and as a treatment for abscesses and boils. Stems and root decoctions are taken against hematuria. Proso millet protein may be useful as a preventive food for certain types of hepatitis.

The vulnerability of society to raising temperature, changing rainfall pattern and increasing climatic extremities has become one of the most discussed issues in global economic, social, scientific and political far. The choice of sowing time was identified as important management options to optimize yield of crop. In Konkan region of Maharashtra with high rainfall and undulating topography, it is cultivated on very light soils on hill slopes where other crops cannot be grown successfully. These lands are often subjected to heavy erosion resulting in continuous reduction in soil fertility status and sub sequent reduction in yield of proso millet. Often, the seed being light in weight and therefore it washed away due to rain water causes reduction in plant population and yield of the crop.

Proso millet is mainly grown by drilling, broadcasting, transplanting and awatni methods. The type of method used gives different yield levels and use of these methods is based on availability of the suitable conditions. In Konkan region, proso millet is cultivated by transplanting and awatnimethods. Among the various agronomic practices, age of the seedling at transplanting and awatni plays very important role in establishment of the crop and further growth, development and yield.

Method of sowing is important agronomic factor affecting the productivity of crop. 
Appropriate sowing method is the important non-monetary input in crop production, which affects the crop growth, yield and quality to greater extent. Method of establishment play important role to fully exploit all available resources for growth as it provides optimum growing condition. Usually transplanting of proso millet is done after rice by "awatni", a traditional method of proso millet cultivation in which seedling are uprooted from nursery and planted by throwing it randomly. Therefore, the establishment of crop is very slow in awatni method as a result; the yield of crop is reduced to greater extent. In other part of the country, mostly proso millet is grown by drilling the seeds. However in Konkan region it is usually grown by raising nurseries and transplanting seedling by awatni in the field. Though transplanted crop give higher yield over the direct sown crop, it is realized that, transplanted crop require more labours for uprooting and transplanting of seedling which are extremely time consuming. The scarcity of labours is being felt for quite some time in the rural area, which leaves no option other than direct sowing of proso millet which is quicker and may become economically viable method. In the broadcasting method initial growth rate is very slow, higher competition for nutrient which is the major characteristic of broadcast method of planting. The systematic study on the performance of proso millet grown by direct seed sowing in comparison with awatni (Farmers practice), broadcasting and recommended transplanting is not conducted in the region.

\section{Materials and Methods}

The present field experiment was conducted during kharif season of 2015 at the Experimental Farm, Agronomy Department, College of Agriculture, Dapoli Dist. Ratnagiri (Maharashtra) Geographically Dapoli is situated in tropical region at 170 4' North latitude and 730 1' East longitude having elevation of 250 meters above the mean sea level. The climate is tropical, warm and humid which is very much favourable for a crop like rice during kharif season. The average annual precipitation of Dapoli is $2269.1 \mathrm{~mm}$ distributed from the beginning of June to September. The soil of the experimental plot was fairly levelled and uniform in topography with well drained conditions. The soil of the experiment plot was sandy clay loam in texture, low in available nitrogen $\left(247.43 \mathrm{~kg} \mathrm{ha}{ }^{-1}\right)$ and phosphorus (10.92 kg ha-1) and moderately high in available potassium (229.62 kg ha-1), very high in organic carbon (11.57) and moderately acidic in reaction $\left(\mathrm{p}^{\mathrm{H}}\right.$ 5.51). The seeds of proso millet were sown at different sowing times viz., $10^{\text {th }}$ Jun $\left(23^{\text {rd }} \mathrm{MW}\right), 24^{\text {th }}$ Jun $\left(25^{\text {th }} \mathrm{MW}\right)$ and $8^{\text {th }}$ July $\left(27^{\text {th }}\right.$ MW) 2015 with different establishment techniques viz., Drilling, Broadcasting, Transplanting and awatni.

The field experiment was laid out in a strip plot design. The vertical factor comprised three sowing times and horizontal factor treatment consisted of four establishment techniques. Thus there were 12 treatment combinations replicated thrice. The treatment details along with symbols used in the layout plan are as follows.

The gross plot size of each experimental unit was $4.2 \mathrm{~m} \times 3.3 \mathrm{~m}$ and net plot size $3.8 \mathrm{~m} \times$ $3.0 \mathrm{~m}$. Pure seed of Proso millet Vari No.10.Proso millet was sown on as per sowing time on nursery bed. The object of dibbling was to maintain fairly uniform plant population in each row Gap filling was undertaken 10 days after sowing to maintain optimum plant stand. 30 days after sowing was done in main field of experiment unit. In awatni techniques, 30 day age old, healthy and vigorous seedlings were uprooted and thereafter, seedlings were transplanted by broadcasting randomly in awatni method as per the treatments in the experimental field 
Treatments

A) Vertical Strip (Sowing times)

1. $23^{\text {rd }} \mathrm{MW}$ ( $4^{\text {th }}$ June to $10^{\text {th }}$ June)

2. $25^{\text {th }} \mathrm{MW}$ (18 $8^{\text {th }}$ June to $24^{\text {th }}$ June)

$3.27^{\text {th }}$ MW ( $2^{\text {nd }}$ July to $8^{\text {th }}$ July)

B) Horizontal Strip- (Establishment techniques)

1. Drilling

2. Broadcasting

3. Transplanting (at $20 \mathrm{~cm} \times 15 \mathrm{~cm}$ )

4. Awatni

Biometric observations and plant characters as an indicators of crop growth viz., Number of panicles sq. $\mathrm{m}^{-1}$, Length of panicle hill ${ }^{-1}$ (g), Weight of panicles hill ${ }^{-1}(\mathrm{~g})$, Test weight or 1000 grains $(\mathrm{g})$, Grain yield $\left(\mathrm{q} \mathrm{ha}{ }^{-1}\right)$, Straw yield $\left(\mathrm{q} \mathrm{ha}^{-1}\right)$ Harvest index (\%)were recorded.

\section{Results and Discussion}

\section{Effect of sowing time}

The grain yield per unit area in proso millet is a function of yield attributes of an individual plant viz., number of panicles square $\mathrm{m}^{-1}$, length of panicle $(\mathrm{cm})$, weight of panicle $(\mathrm{g})$ and ultimately the grain and straw yield obtained from the plant.

Sowing of proso millet in $25^{\text {th }} \mathrm{MW}$ recorded maximum and significantly higher grain yield (Table 1 ) over $23^{\text {rd }} \mathrm{MW}$, and $27^{\text {th }} \mathrm{MW}$. This may due to the increased plant height, number of leaves square $\mathrm{m}^{-1}$, dry matter accumulation square $\mathrm{m}^{-1}$ and number of tillers square $\mathrm{m}^{-1}$ and length of light availability was more under the treatment sowing $25^{\text {th }} \mathrm{MW}$. The food material produced by the green leaves that is nothing but site of action where it produced, during initial growth period it was used by the plant for their structural development that leads to increased number of leaves, height and tillers and thereafter the potential physiological growth attain by the

\section{Symbols used}

$S_{1}$
$S_{2}$
$S_{3}$
$M_{1}$
$M_{2}$
$M_{3}$
$M_{4}$

crop plant, whatever food material produced is utilized by crop plant by diverting all food material, i.e. photosynthates towards development of reproductive organs of crop plant that is flower, grain, their length etc. i.e. more is source and ultimately more food material produced which was diverted toward the sink i.e. yield attributing characters and reflect on yield observed in $25^{\text {th }} \mathrm{MW}$. These finding were in conformity with Amanullah Jan et al., (2012) in rice.

\section{Effect of establishment method}

The grain yield per unit area in proso millet is a function of yield attributes of an individual of plant viz., number of panicles square $\mathrm{m}^{-1}$, length of panicle $(\mathrm{cm})$, weight of panicle $(\mathrm{g})$ and ultimately the grain yield obtained from the plant. The result revealed that transplanting $\left(\mathrm{M}_{3}\right)$ techniques of establishment higher than awatni $\left(\mathrm{M}_{4}\right)$ in some these yield contributing characters and improved the yield attribute (Table 1) and thereby grain yield ha ${ }^{-1}$ (Table 1) over drilling $\left(\mathrm{M}_{1}\right)$ and broadcasting $\left(\mathrm{M}_{2}\right)$. However, drilling $\left(\mathrm{M}_{1}\right)$ and broadcasting $\left(\mathrm{M}_{2}\right)$ were at par with each other in some of the yield attributes. Transplanting $\left(\mathrm{M}_{3}\right)$ was significantly superior over awatni $\left(\mathrm{M}_{4}\right)$ in respect of number of panicles square $\mathrm{m}^{-1}$, length of panicle $(\mathrm{cm})$, weight of panicle $(\mathrm{g})$ and thereby the grain yield $\mathrm{ha}^{-1}$. 
Table.1 Mean growth character and yield attributes character as influenced by different sowing time and establishment techniques on proso millet

\begin{tabular}{|c|c|c|c|c|c|c|c|c|}
\hline Treatments & $\begin{array}{c}\text { Plant } \\
\text { height }(\mathrm{cm})\end{array}$ & $\begin{array}{c}\text { Functional } \\
\text { leaves } \\
\left(\text { square } \mathbf{m}^{-1} \text { ) }\right.\end{array}$ & $\begin{array}{l}\text { Number of } \\
\text { tillers } \\
\text { square } \mathbf{m}^{-1}\end{array}$ & $\begin{array}{c}\text { Dry } \\
\text { matter g } \\
{\text { square } \mathbf{m}^{-1}}_{(\mathrm{g})}\end{array}$ & $\begin{array}{c}\text { No. of } \\
\text { Panicles } \\
\left(\text { square } \mathbf{m}^{-1}\right)\end{array}$ & $\begin{array}{c}\text { Length of } \\
\text { panicle }(\mathrm{cm})\end{array}$ & $\begin{array}{l}\text { Weight of } \\
\text { panicle (g) }\end{array}$ & $\begin{array}{l}\text { Test wt. } \\
(1000 \\
\text { grains (g) }\end{array}$ \\
\hline \multicolumn{9}{|l|}{ A) Sowing times } \\
\hline $\mathbf{S}_{\mathbf{1}^{-}} 23^{\text {rd }} \mathrm{MW}$ & 118.40 & 325.42 & 102.33 & 559.83 & 90.50 & 30.17 & 10.75 & 1.65 \\
\hline $\mathbf{S}_{2^{-}} 25^{\text {th }} \mathrm{MW}$ & 123.83 & 331.17 & 107.00 & 583.58 & 95.33 & 31.94 & 10.82 & 1.68 \\
\hline $\mathbf{S}_{3^{-}} 27^{\text {th }} \mathrm{MW}$ & 117.50 & 324.50 & 100.67 & 554.83 & 89.50 & 29.66 & 10.53 & 1.61 \\
\hline F. test & Sig. & Sig. & Sig. & Sig. & Sig. & Sig. & N.S & N.S. \\
\hline S.Em. \pm & 0.75 & 1.05 & 1.12 & 4.56 & 0.98 & 0.28 & 0.10 & 0.04 \\
\hline C.D. at $5 \%$ & 2.31 & 3.22 & 3.45 & 14.06 & 3.02 & 0.86 & - & - \\
\hline \multicolumn{9}{|c|}{ B) Establishment techniques } \\
\hline $\mathbf{M}_{\mathbf{1}^{-}}$Drilling & 120.92 & 309.78 & 101.44 & 372.22 & 92.33 & 30.28 & 10.15 & 1.65 \\
\hline $\mathbf{M}_{2}$ - Broadcasting & 121.72 & 300.44 & 95.78 & 350.33 & 90.56 & 28.59 & 9.13 & 1.53 \\
\hline $\mathbf{M}_{\mathbf{3}^{-}}$Transplanting & 119.22 & 354.11 & 110.33 & 782.11 & 97.11 & 32.44 & 12.36 & 1.74 \\
\hline $\mathbf{M}_{4^{-}}$Awatni & 117.78 & 343.78 & 105.78 & 759.67 & 87.11 & 31.04 & 11.16 & 1.68 \\
\hline F. test & N.S. & Sig. & Sig. & Sig. & Sig. & Sig. & Sig. & N.S. \\
\hline S.Em. \pm & 2.05 & 2.72 & 1.64 & 10.22 & 1.27 & 0.37 & 0.15 & 0.05 \\
\hline C.D. at $5 \%$ & - & 8.38 & 5.06 & 31.49 & 3.91 & 1.13 & 0.47 & - \\
\hline \multicolumn{9}{|l|}{ Interaction effect } \\
\hline F. test & N.S. & N.S. & N.S. & N.S. & N.S. & N.S. & N.S. & N.S. \\
\hline S.Em. \pm & 3.41 & 2.22 & 3.59 & 34.00 & 3.61 & 0.66 & 0.46 & 0.04 \\
\hline C.D. at $5 \%$ & - & - & - & - & - & - & - & - \\
\hline General mean & 119.91 & 327.03 & 103.33 & 566.08 & 91.78 & 30.59 & 10.70 & 1.65 \\
\hline
\end{tabular}


The increase in grain yield recorded under transplanting $\left(\mathrm{M}_{3}\right)$ over awatni $\left(\mathrm{M}_{4}\right)$, drilling $\left(\mathrm{M}_{1}\right)$ and broadcasting $\left(\mathrm{M}_{2}\right)$ respectively. Similarly, increase in grain yield recorded in awatni $\left(\mathrm{M}_{4}\right)$ over drilling $\left(\mathrm{M}_{1}\right)$ and broadcasting $\left(\mathrm{M}_{2}\right)$ of seeds were $5.50,18.02$ and 27.19 per cent, respectively. Similarly, increase in grain yield recorded in awatni over drilling and broadcasting of seeds was 11.86 and 20.55 per cent, respectively. The increased yield attributes might be due to increased growth and development parameters and increased grain yield might be due to increased yield attributes. In spite of high plant population in broadcasting $\left(\mathrm{M}_{2}\right)$ and drilling $\left(\mathrm{M}_{1}\right)$ the yield $\mathrm{ha}^{-1}$ was adversely affected. As matter of fact, the yield of unit area basis was higher with lower plant population. In other hand lower yield plant ${ }^{-1}$ was nullified because of high number of plant in broadcasting $\left(\mathrm{M}_{2}\right)$ drilling $\left(\mathrm{M}_{1}\right)$ and awatni $\left(\mathrm{M}_{4}\right)$. The present results are in consonance with those of Ravi (1984) and Newase et al., (1995) in finger millet and Tippangoudar (2009) in proso millet, respectively. Transplanting $\left(\mathrm{M}_{3}\right)$ of proso millet recorded higher straw yield (Table 1) over awatni $\left(\mathrm{M}_{4}\right)$ drilling $\left(\mathrm{M}_{1}\right)$ and broadcasting $\left(\mathrm{M}_{2}\right)$ of seeds was $10.80,29.92$ and 35.31 per cent, respectively. This might due to increased morphological characters viz., plant height, and number of leaves sq. $\mathrm{m}^{-1}$, number of tillers sq. $\mathrm{m}^{-1}$ and dry matter production sq. $\mathrm{m}^{-1}$ observed under transplanting $\left(\mathrm{M}_{3}\right)$. Similar findings were also reported by Tippangoudar (2009) in proso millet, respectively.

Thus the result clearly showed that transplanting $\left(\mathrm{M}_{3}\right)$ techniques of establishment was superior followed by awatni $\left(\mathrm{M}_{4}\right)$ for obtained higher grain and straw yield ha ${ }^{-1}$ from proso millet.

\section{References}

Anonymous. 2013. Research Review Committee report 2013 under, All India Coordinated Research Project on Agro Meteorology, held at Dr. B.S.K.K.V. Dapoli Dist. Ratnagiri (M.S.).

Anonymous. 2010. Published on Food and Agriculture Organization Web site. Http: // www.fao.org

Amanullah, Jan., Khan, I., Ali, S. and Sohail, A.A. 2012. Sowing Dates and Sowing Methods Influenced on Growth Yield and Yield Components of Pearl Millet under Rainfed Conditions, J. Env. and Earth Sci., 5(1): 104-107.

Narayanswamy, Y., Yogeswara Rao, Ramahaiah, K. and Rao, S. 1982. Effect of time and method of sowing rice varieties in puddled soil during wet season. Oryza, 19(1): 47-52.

Tippangoudar, P.G. 2009. Studies on comparative performance of proso millet (Panicum miliaceum L.) under methods of sowing and weed management. M.Sc. (Agri.) Thesis submitted to the Dr. B.S.K.K.V. Dapoli (unpublished).

Ravi, N. 1984. Influence of planting time and method of establishment on the growth and yield of rainfed ragi. Mysore J. Agric. Sci., 21(4): 23-27.

Newase, V.B., Thorat, S.T and Chavan, S.A. 1995. Effect of methods of planting and fertilizer application on the yield of kharif ragi. J. Indian Soc. Agric. Res., 13(2): 151152.

\section{How to cite this article:}

Gavit, H.D., V.A. Rajemahadik, G.K. Bahure, M.S. Jadhav, T.N. Thorat and Kasture, M.C. 2017. Effect of Establishment Techniques and Sowing Time on Yield and Yield Attributes of Proso Millet (Panicum miliaceum L.). Int.J.Curr.Microbiol.App.Sci. 6(5): 1523-1528. doi: https://doi.org/10.20546/ijcmas.2017.605.166 